\title{
Kontekst jest do bani
}

\section{Rita Felski}

Niniejszy tytuł to niezbyt subtelna prowokacja, która - muszę zaznaczyć - nie jest mojego autorstwa. Czy istnieje jakieś słowo, które byłoby bardziej wszechobecne w badaniach literackich i kulturowych, słowo, które solenniej przywołujemy, gorliwiej bierzemy w obronę, takie, któremu nabożniej się kłaniamy? Niegdyś wszechobecne, a dziś śmieszne pojęcie „dzieła jako takiego" jest nieustannie rozkrawane, rozczłonkowywane i wysyłane do zapomnianej krainy Nowej Krytyki. Kontekst nie jest fakultatywny. Między różnymi poddziedzinami i odłamami toczą się oczywiście spory o to, co kwalifikuje się jako zasadny kontekst: krytycy marksistowscy czują się urażeni anegdotami i stylami opisu społecznego badaczy spod znaku nowego historyzmu, a teoretycy queer nie zgadzają się z wyjaśnieniami feministycznymi, które zakładają świat dwubiegunowy genderowo. W tym sensie kontekst jest pojęciem nieustannie kwestionowanym, celem niejednokrotnie złośliwych przeróbek i sporadycznych serii sekciarskich strzałów z ukrycia. Ale kto przy zdrowych zmysłach - poza kilkorgiem twardogłowych estetów mamroczących nad kieliszkami sherry - mógłby rzeczywiście nie zgadzać się z samą ideą kontekstu?

„Kontekst jest do bani” to tak naprawdę podwójny cytat: mój tytuł prowadzi do Bruno Latoura, który z kolei cytuje architekta Rema Koolhaasa ${ }^{1}$. Ale w jakim celu? Latour jest w końcu jednym z najbardziej rozpoznawalnych rzeczników badań nad nauką, czyli dziedziny, która storpedowała ideę nauki jako wytrwałego dążenia do prawdy, drobiazgowo dokumentując jej społeczne osadzenie oraz zanieczyszczenie wpływem świata. Tymczasem moje badania zawdzięczają wiele feministycznemu historyzmowi oraz metodologii badań kulturowych, które uznają kontekstualizację za najwyższą cnotę. Stwierdzenie Larry’ego Grossberga, że „dla badań kulturowych kontekst jest wszystkim, a wszystko jest kontekstowe" zwięźle podsumowuje najgłębiej żywione przeświadczenia tej dziedziny². Co zatem kryje się za tym nagłym atakiem na ulubione słowo współczesnych badań literackich i kulturowych?

Historia teorii literatury rzeczywiście zawiera litanię skarg przeciwko kontekstualizacji: od twierdzenia rosyjskich formalistów, że forma literacka rozwija się autonomicznie, po obstawanie Gadamera przy tym, że dzieło sztuki nie jest tylko historycznym artefaktem, lecz zostaje

\footnotetext{
${ }^{1}$ B. Latour, Splatając na nowo to, co społeczne. Wprowadzenie do teorii aktora-sieci, wstęp K. Abriszewski, przeł.

A. Derra, K. Abriszewski, Kraków 2010, s. 213.

${ }^{2}$ L. Grossberg, Bringing It All Back Home: Essays on Cultural Studies, Durham, NC 1997, s. 255.
} 
na nowo zaktualizowane i wskrzeszone w hermeneutycznym spotkaniu. W bliższej przeszłości myśliciele-dekonstrukcjoniści przypuścili żywiołowy atak na jakiekolwiek pojęcie historii lub kontekstu rozumiane jako stabilna podstawa i ostrzegli przed zagrożeniami przekontekstualizowania, które odnosi się przemocowo do obiektu literackiego. Fakt, że takie argumenty w niewielkim stopniu powstrzymały obecną falę historyzmu ma, według mojej hipotezy, dwie główne przyczyny. Po pierwsze, argumenty owe opierają się czasem na rozróżnieniu „tekstów niezwykłych”, które wykraczają poza swój moment historyczny, oraz tekstów „konwencjonalnych” czy „stereotypowych”, które są przez niego determinowane, przez co przywracają - coraz mniej przekonującą dla wielu badaczy - dychotomię kultury wysokiej i niskiej. Po drugie, odrzucenie kontekstu może poskutkować oderwaną od rzeczywistości koncentracją na języku poetyckim, formie i tekstualności, daleką od nieuporządkowanych, przyziemnych, empirycznych szczegółów związanych z tym, jak i po co czytamy. Stwierdzenie, że przeprowadzone $\mathrm{w}$ inny sposób zakwestionowanie kontekstu może przyczynić się do poświęcenia większej uwagi takim szczegółom, to jedna ze sprzecznych z intuicją tez tego artykułu. Podążając za Latourem można powiedzieć, że kontekst, „to po prostu sposób na zatrzymanie opisu, kiedy się jest zmęczonym lub zbyt leniwym, aby go kontynuować”3.

Moje własne wątpliwości dotyczące kontekstu są związane z szerszą refleksją nad rolą krytycznego czytania w najnowszej historii badań literackich. „Hermeneutyka podejrzeń” to nazwa nadawana zwykle technice czytania tekstów pod włos i między wierszami, katalogowania zawartych w nich przeoczeń, odsłaniania ich sprzeczności oraz podkreślania tego, czego nie wiedzą i nie są w stanie przedstawić. Choć podejrzliwość może się manifestować na wiele sposobów, w obecnym klimacie intelektualnym zwykle opiera się na lennym stosunku wobec wyjaśniającej mocy kontekstu historycznego. Według tej linii rozumowania tekst literacki nie widzi szerszych okoliczności, które kształtują go i podtrzymują, a które wydobywa na światło dzienne korygująca moc czujnego oka krytyka. Krytyk poszukuje znaczeń niedostępnych dla autorów i zwykłych czytelników, i ujawnia współudział tekstu w warunkach społecznych, którego chce się on wyprzeć lub któremu stara się zaprzeczyć. Kontekst, jako pełniejsza, rozleglejsza perspektywa, niezmiennie przewyższa twierdzenia pojedynczego tekstu, znając go o wiele lepiej, niż on sam mógłby się kiedykolwiek poznać.

Wbrew takiemu krytycznemu historyzmowi chcę wyartykułować i uzasadnić dwa twierdzenia: 1) historia nie jest szufladką - konwencjonalne modele historycyzacji i kontekstualizacji nie wystarczają, by wyjaśnić transtemporalny ruch i afektywny rezonans poszczególnych tekstów oraz 2) by lepiej oddać sprawiedliwość temu transtemporalnemu wpływowi, moglibyśmy z pożytkiem myśleć o tekstach jako „aktorach poza-ludzkich” - które to twierdzenie, jak zobaczymy, wymaga zrewidowania dominujących poglądów na temat heroicznej, samonapędzającej się albo skłonnej do sprzeciwu natury sprawczości oraz przemyślenia związków między sprawczością a załącznikiem [attachment ${ }^{4}$ ]. Ostatnie prace Bruno Latoura stanowią częściową inspirację dla tego, o czym będę mówić: wynika ona nie tyle z objaśnień konkretnych dzieł literackich - na temat których Latour jak dotąd powiedział niewiele - ile z zawartej w nich sprytnej prowokacji wobec naszych

\footnotetext{
${ }^{3}$ B. Latour, Splatajac na nowo..., s. 213.

${ }^{4}$ Tam, gdzie to możliwe, zwłaszcza w kontekście dzieła Latoura, tłumaczymy „attachment(s)” jako „załącznik(i)”, zgodnie z polskim przekładem Splatając na nowo to, co społeczne autorstwa Aleksandry Derry i Krzysztofa Abriszewskiego [przyp. tłum.].
} 
głęboko zakorzenionych sposobów myślenia o tekstach i czasie, rzeczach i osobach, działaniu i współdziałaniu. Podkreślając różne przeskoki między nastrojem i metodą, bujny idiom Latoura zdmuchuje pajęczyny krytyki i wstrząsa wszechobecnym akademickim etosem dystansu, negatywności i wątpienia. Lektura podejrzliwa, jak argumentowałam w innym miejscu, to nie po prostu ćwiczenie intelektualne, lecz odrębna dyspozycja czy też wrażliwość, która jest nasycona mieszanką postaw i afektów. Eksperymentowanie z innymi trybami czytania i rozumowania będzie od nas wymagało nie tylko innego myślenia, ale być może również innego odczuwania ${ }^{5}$.

\section{Historia nie jest szufladką}

Po kilku dekadach badań zorientowanych historycznie krytycy na nowo zwracają się ku kwestiom estetyki, piękna i formy, przytaczając porażki historyzmu, który traktuje dzieła sztuki wyłącznie jako kulturowe symptomy ich momentu historycznego, jako konającą materię zagrzebaną w przeszłości. Jednak rażąco widać, że ten nowy estetyzm nie daje odpowiedzi na pytanie, jak teksty rezonują w czasie. Ponieważ skupia się on na narzędziach formalnych albo fenomenologii doświadczenia estetycznego, raczej bierze w nawias niż rozwiązuje problem czasowości. Nie możemy zamykać oczu na historyczność dzieł sztuki, jednak pilnie potrzebujemy alternatywy dla postrzegania ich albo jako transcendentalnie bezczasowych, albo jako uwięzionych w momencie swojego powstania.

Temu niedostatkowi modeli temporalnych można przeciwstawić dostępność licznych źródeł umożliwiających konceptualizację przestrzeni. Zwłaszcza badania postkolonialne zmieniły nasz sposób myślenia na temat tego, jak idee, teksty i obrazy migrują oraz mutują. Kwestionując pojęcia odrębnych, niezależnych przestrzeni narodu czy etniczności, badacze rozwinęli język translacji, kreolizacji, synkretyzmu i globalnych przepływów. Podobne modele mogą pomóc nam badać złożoność transmisji temporalnej. Dlaczego dzieje się tak, że czujemy się przyciągnięci, zagadnięci, poruszeni przez słowa, które zostały nakreślone całe wieki temu? Jak to się dzieje, że teksty, które w jednym momencie historycznym są bezwładne, w innym stają się odkrywcze, otwierają oczy, a nawet przekształcają życie? I w jaki sposób takie momenty transtemporalnego związku kwestionują narracje o postępie, które napędzają konwencjonalne historie polityczne i retorykę artystycznej innowacji?

Badania postkolonialne zakłócają oczywiście nasze modele czasu i przestrzeni, wywracając ład kategorii periodyzacyjnych i oświetlając sposoby, w jakie historyczne schematy często wzmacniają samozadowolenie zachodocentrycznego punktu widzenia. Zadanie „prowincjonalizacji Europy", według znanego sformułowania Dipesha Chakrabarty'ego, zachęca nas do przemyślenia od samych podstaw tego, w jaki sposób i w jakim celu uhistoryczniamy i kontekstualizujemy. Podobne zniecierpliwienie historyzmem zaczyna być odczuwalne w całych badaniach literackich. Choć nie możemy jeszcze mówić o szkole posthistorycznej, toczy się mnóstwo pomniejszych rebelii i rewolt na małą skalę wywołanych przez badaczy rozważających kwestię „czasu po historii”. Teoretycy queer postulują „nie-historyzm” otwarty na powinowactwa między czasami wcześniejszymi i naszymi, który nie boi się haseł bliskości i anachronizmu. Badacze renesansu odzyskują termin „prezentystyczny” jako powód do chwały, a nie lekceważącą kpinę, bez żenady przyznając się do większego zainteresowania dzisiejszą istotnością sztuk Szekspira niż ich oddziaływaniem historycznym. Krytycy literaccy obwieszczają swoje

\footnotetext{
${ }^{5}$ R. Felski, Suspicious Minds, „Poetics Today” 2011, 32, nr 2, s. 215-234.
} 
nawrócenie na ikonoklastyczne prace Michela Serresa, który zachęca nas do myślenia o czasie nie jako o strzałce, ale jak o falującym wężu, a nawet zmiętej chusteczce. W tle zaś unosi się oczywiście święta figura Waltera Benjamina, patrona wszystkich nieufnych wobec projektów periodyzacji, chronologicznego odgradzania i linearnych opowieści ${ }^{6}$.

Jakie konsekwencje dla badań literackich i kulturowych mają te temporalne zawirowania? Osobliwą wadą „konceptu kontekstu” jest to, że podstępnie nakłania nas do niekończącego się powtarzania tych samych dychotomii: tekst versus kontekst, słowo versus świat, literatura versus społeczeństwo i historia, internalistyczne versus eksternalistyczne wyjaśnienia dzieł sztuki. Badania literackie wydają się skazane na wahanie między tymi biegunami, a strony sporu będą bez końca i jałowo przerabiać te same argumenty. „Jesteście tak absurdalnie naiwni i idealistyczni!” - krzyczą kontekstualiści. „Wasze krótkowzroczne skupienie na słowie drukowanym sprawia, że stajecie się ślepi na nieunikniony wpływ sił społecznych i ideologicznych!”. „Jesteście tacy redukcjonistyczni i niezgrabni” - utyskują formaliści. „Możecie do znudzenia prawić kazania o energiach społecznych i patriarchalnych ideologiach, ale wasze teorie kontekstu i tak są całkowicie głuche na to, co sprawia, że obraz jest obrazem, a wiersz jest wierszem!”. Z pewnością istnieją różne historyzmy i wiele typów polityczności, ale zadanie oddania sprawiedliwości specyfice i odrębności dzieł sztuki pozostaje niezmiennie ich solą w oku. Słynna dowcipna uwaga Sartre’a, że Valéry był drobnomieszczańskim intelektualistą, ale nie każdy drobnomieszczański intelektualista był Valérym zachowuje wiele ze swojej uszczypliwej mocy. A jednak i my doskonale wiemy, że dzieła sztuki nie spadają z nieba, że nie szybują jak anioły ponad powierzchnią ziemi, że muszą pomoczyć sobie buty i ubrudzić ręce. Jak oddać sprawiedliwość zarówno ich jednostkowości, jak i ich światowości?

Jedna z głównych przeszkód tkwi w dominującym wyobrażeniu kontekstu jako szufladki albo pojemnika, w którym pojedyncze teksty są zamknięte i dobrze zabezpieczone. Krytyk przypisuje tej szufladce listę atrybutów - strukturę ekonomiczną, ideologię polityczną, mentalność kulturową - by zręcznie ominąć szczegóły tego, jakim w konkretnym dziele sztuki te atrybuty rozbrzmiewają echem, jak są modyfikowane albo podważane. Makropoziom kontekstu społeczno-historycznego ma wszystkie atuty w ręku, gra pierwsze skrzypce i ustala zasady gry; pojedynczy tekst, jako mikrojednostka zamknięta w większej całości, może tylko reagować albo odpowiadać na owe ustalone wcześniej warunki. W tym świetle historia składa się ze starannie ułożonych jedna na drugiej szufladek - zwanych przez nas epokami - z których każda otacza, podtrzymuje i zawiera mikrokulturę. Rozumieć tekst, znaczy szczegółowo wyjaśniać jego umiejscowienie w szufladce, podkreślając korelacje, związki przyczynowe albo homologie między tekstem-jako-obiektem a kontekstem-jako-pojemnikiem.

Oczywiście nowy historyzm dzielnie zmaga się z żelaznym uściskiem podziału tekst/kontekst. Zaświadczając, w często cytowanej frazie, o historyczności tekstów i tekstualności historii, mąci

\footnotetext{
${ }^{6}$ Zob. na przykład: J. Goldberg, M. Menon, Queering History, „PMLA” 2005, 120, nr 5, s. 1608-1617; C. Dinshaw $\mathrm{i}$ in., Theorizing Queer Temporalities: A Roundtable Discussion, „GLQ” 2007, 13, nr 2-3, s. 177-195; Presentist Shakespeare, red. H. Grady, T. Hawkes, London 2006; J.J. Cohen, Medieval Identity Machines, Minneapolis 2003; J. Summit, D. Wallace, Rethinking Periodization, „Journal of Medieval and Early Modern Studies” 2007, 37, nr 3, J.G. Harris, Untimely Matter in the Time of Shakespeare, Philadelphia 2009; J. Bowen, Time for Victorian Studies?, „Journal of Victorian Culture” 2009, 14, nr 2, s. 282-293; E. Cohen, Confessions of a Pseudo-Victorianist, Or How I fell Ass-Backwards and Landed in a Period (a Screed), „Victorian Literature and Culture” 1999, 27, nr 2, s. 487-494.
} 
i miesza granice między słowem a światem. Dzieła sztuki nie majaczą już jak potężne monumenty na historycznym tle, które jest materialnie determinujące, ale semiotycznie bierne. Zamiast tego sama historia okazuje się tętniącą życiem wielością tekstów - pamiętników odkrywców, sprawozdań sądowych, poradników wychowania dzieci, dokumentów rządowych, gazetowych wstępniaków - których obieg zabezpiecza transmisję energii społecznych. Na tej samej zasadzie dzieło literackie nie przekracza tych monotonnych okoliczności, lecz pozostaje nieszczęśnie, beznadziejnie i mocno wplątane w włókna władzy, jako jeszcze jeden społeczny tekst wśród innych.

A jednak, choć najważniejszy tekst nowego historyzmu ogłosił słynne pragnienie rozmawiania ze zmarłymi, większości prac powstałych pod tą etykietą bliżej do diagnozy niż dialogu, gdyż stwarzają poczucie niedającej się zasypać przepaści między przeszłymi tekstami i teraźniejszym życiem, między „wtedy” a „teraz”. Historyzm służy za funkcjonalny ekwiwalent relatywizmu kulturowego, różnicę poddaje kwarantannie, zaprzecza pokrewieństwu i zawiesza - albo mniej delikatnie, usuwa - pytanie, dlaczego przeszłe teksty nadal się liczą i jak do nas przemawiają. Oczywiście teoretycznym banałem stało się stwierdzenie, że nie możemy nigdy poznać przeszłości takiej, jaką naprawdę była, że historia jest zawsze, przynajmniej częściowo, historią teraźniejszości. We wprowadzeniach, wstępach i posłowiach badacze często przyznają się do obecnych pasji i deklarują polityczną przynależność. Jednak te wyznania rzadko przekładają się na transhistoryczne metodologie albo poszukiwanie ponadczasowych sieci. Jest raczej tak, że przedmiot literacki pozostaje uwieziony wewnątrz warunków, które zarządzają momentem jego narodzin, jego znaczenie zostaje określone na podstawie relacji do tekstów i obiektów z tego samego momentu, a on sam na stałe zaetykietowany jako artefakt nowożytny, osiemnastowieczny albo wiktoriański. Wai Chee Dimock nazywa to „synchronicznym historyzmem", wedle którego zjawiska są spokrewnione tylko ze zjawiskami z tego samego odcinka czasowego ${ }^{7}$. Wpaja się nam, w imię historii, wyjątkowo statyczny model znaczenia, w którym teksty są otoczone dawno przebrzmiałymi kontekstami i przestarzałymi intertekstami, uwięzione w przeszłości bez nadziei na zwolnienie warunkowe.

Dla Latoura natomiast nie istnieje historyczna szufladka ani nawet społeczeństwo, jeśli przez ten termin rozumiemy odrębną, wyznaczoną totalność rządzoną przez z góry ustalony zbiór struktur i funkcji. Nie jest tak, że społeczeństwo, przypominające zagadkowego, wszystko widzącego marionetkarza, stoi za ludzkimi praktykami i potajemnie je kontroluje, jakby było od nich ontologicznie odrębne. To, co społeczne, to raczej akt i fakt tworzenia powiązań, łączne występowanie zjawisk tworzących liczne asamblaże, powinowactwa i sieci. Istnieje tylko w swoich przejawach, w czasem przewidywalnych, a czasem nieprzewidywalnych sposobach, w które idee, teksty, obrazy, ludzie i przedmioty łączą się i rozłączają, przyłączają i rozpadają. Uprawianie teorii aktora-sieci (ANT) nie polega na tym, by szybować jak orzeł, spoglądając beznamiętnie na znajdującą się w dole wielość, ale mozolnie maszerować jak mrówka (ANT), zachwycając się kunsztownymi ekologiami i różnorodnymi mikroorganizmami, które leżą ukryte w bujnych źdźbłach trawy. Polega na zwalnianiu na każdym kroku, rezygnowaniu z teoretycznych skrótów i na zwracaniu uwagi na słowa naszych współaktorów, a nie uchylaniu ich - i przepisywaniu - za pomocą własnych. To, co społeczne, innymi słowy, nie jest odgry-

\footnotetext{
${ }^{7}$ W.Ch. Dimock, A Theory of Resonance, „PMLA” 1997, 112, nr 5, s. 1061. Interesujący niedawny przykład porównywania transtemporalnego, zob. L.M.E. Goodlad, Trollopian „Foreign Policy”: Rootedness and Cosmopolitanism in the Mid-Victorian Global Imaginary, „PMLA” 2009, 124, nr 2, s. 437-454.
} 
wanym byciem, lecz działaniem, nie ukrytym bytem tkwiącym u podstaw świata zjawisk, ale nieustannymi połączeniami - zawiązywanymi, zrywanymi i na powrót nawiązywanymi - między niezliczonymi aktorami.

Te związki są zarówno temporalne, jak i przestrzenne; splecione z nici krzyżujących się na przestrzeni czasu, łączą nas z tym, co było wcześniej, wikłając w rozbudowane sieci obowiązku i wpływu. Czas nie jest uporządkowaną sekwencją rozdzielonych części, lecz wielością wodnych lejów i prądów, wirów i przepływów, w których przedmioty, idee, obrazy i teksty $\mathrm{z}$ różnych momentów kłębią się, kotłują i zderzają w nieustannie zmiennych kombinacjach i konstelacjach. Nowi aktorzy walczą przy ich boku z tysiącletnimi historiami; wynalazki i innowacje współistnieją z tymi właśnie tradycjami, które ostro krytykują; „przeszłość nie jest przekraczana, ale przetwarzana, powtarzana, otaczana, chroniona, rekombinowana, reinter-

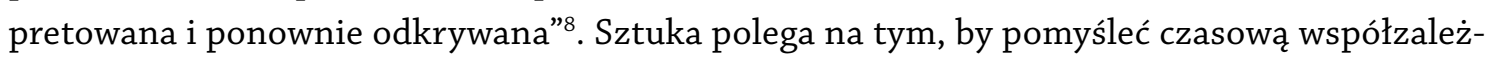
ność bez telosu, ruch bez następstwa: przeszłościowość jest częścią tego, kim jesteśmy, nie archaicznym residuum, siłą regresywną, źródłem nostalgii albo powrotem wypartego. Głośne twierdzenie Latoura, że nigdy nie byliśmy nowocześni, nie kwestionuje faktu, że nasze życia różnią się od tych, jakie wiedli średniowieczni chłopi albo renesansowi dworzanie, ale podkreśla, że te różnice mogą być absurdalnie przerysowane na skutek naszego zamiłowania do racjonalizujących bajek, odczarowania świata, rozdzielenia podmiotów od przedmiotów, radykalizmu nowoczesnej krytyki i innych świadectw naszego własnego wyjątkowego statusu.

Na podobnej zasadzie Jonathan Gil Harris nie zgadza się z tym, co nazywa „modelem czasu wzorowanym na rozumieniu narodowej suwerenności" [national sovereignty model of time], który występuje endemicznie w badaniach literackich i kulturowych. Innymi słowy, epoka pełni w dużej mierze tę samą funkcję co naród; przypisujemy teksty i przedmioty do danego momentu powstania w podobny sposób jak kojarzymy je z jednym miejscem powstania. Zarówno epoka, jak i naród służą jako naturalna granica, rozstrzygający autorytet i sąd ostatniej instancji. Dzieło literackie może być obywatelem tylko jednej epoki historycznej i jednego zestawu relacji społecznych; dzieło jest nieustannie strzeżone przez granicę, każdy ruch poza granice epoki jest pilnie nadzorowany. Przeszłość pozostaje krajem obcym, nieznanym i zagadkowym, a jego odmienność jest nieustannie podkreślana. „Co zrobić” - zastanawia się Harris - „z rzeczami, które przekraczają czasowe granice - rzeczami, które są nielegalnymi imigrantami, podwójnymi agentami albo posiadaczami podwójnych paszportów? Jak takie przekroczenia granicy

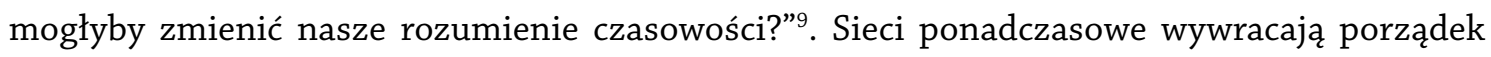
naszych modeli periodyzacyjnych, zmuszając nas do uznania powinowactwa i bliskości, a nie tylko różnicy; borykania się z równoczesnością oraz połączeniem przeszłości i teraźniejszości.

Ta linia rozumowania w oczywisty sposób kłóci się z Foucaultowskim modelem krytyki, który przedstawia przeszłość jako serię rozłącznych episteme i który zachęca krytyka do analizowania egzotycznych postaw z wcześniejszych czasów ze skrupulatną, ascetyczną beznamiętnością. Zamiast absolutnej temporalnej różnicy i dystansu mamy nieuporządkowaną mieszaninę i spory mętlik, wyciek na styku epok, w który jesteśmy całkowicie wplątani, opisując zjawiska

\footnotetext{
${ }^{8}$ B. Latour, Nigdy nie byliśmy nowocześni: studium z antropologii symetrycznej, przeł. M. Gdula, Warszawa 2011, s. 108.

9 J.G. Harris, Untimely Matter..., s. 2.
} 
historyczne. Teoria aktora-sieci jest w równym stopniu zdeprymowana modernistyczną wizją czasu jako zerwania, które uwalnia nas od pogrążonej w mrokach niewiedzy przeszłości. $\mathrm{Na}$ skutek wszechobecności ponadczasowych sieci niespójny staje się nie tylko klasyczny model rewolucji, ale i etos awangardy - tych kilkorga namaszczonych, którzy dzięki swojemu intelektualnemu przygotowaniu, politycznym przekonaniom lub artystycznej wrażliwości wyprowadzają siebie samych z mgły pomyłek i złej wiary, w której pogrążeni są inni. Historia nie idzie naprzód i nikt $\mathrm{z}$ nas nie przewodzi.

Krótko mówiąc, dlaczego jesteśmy przekonani, że wiemy więcej niż teksty, które nas poprzedzają? Przewagę naszej perspektywy czasowej równoważy ich solidność, odporność i wciąż trwający rezonans. Ich czasowość jest dynamiczna, a nie ustalona czy zastygła; mówią o momencie, z którego pochodzą, ale też o czymś, co poza niego wykracza, antycypując przyszłe powinowactwa i wywołując jak dotąd niewyobrażalne połączenia. W swoim przejrzystym rozliczeniu z historyzmem Jennifer Fleissner zachęca nas do lektury dziewiętnastowiecznych powieści jako żywej myśli, a nie ucieleśnienia dawnej pracy kulturowej, jak głosów, które reagują na nasze własne modele wyjaśniające i schematy klasyfikacyjne ${ }^{10}$. Nie jest tak, że kontekst automatycznie czy nieuchronnie zwycięża z tekstem, ponieważ samo pytanie, co kwalifikuje się jako kontekst oraz moc przekonywania naszych schematów przyczynowych i wyjaśniających mogą być antycypowane, eksplorowane, kwestionowane, relatywizowane, rozszerzane albo ponownie wyobrażane w słowach, które czytamy (a nie tylko „zakłócane” jak chciałyby zwulgaryzowane wersje dekonstrukcji). Obiektywizm historycznego wyjaśnienia zostaje zwichrzony, a nawet nadszarpnięty, kiedy dostrzegamy, że przeszłe teksty mają coś do powiedzenia w kwestiach, które się dla nas liczą, w tym w kwestii samego statusu rozumienia historycznego.

To aktywne dalsze życie literackiego artefaktu opiera się naszym wysiłkom zaszufladkowania go do momentu powstania, zaryglowania w temporalnym pojemniku. Moment narodzin dzieła nakłada oczywiście ograniczenia na temat, formę i gatunek; na próżno szukamy znaków modernistycznego spleenu w wierszach attyckich albo dadaistycznego decoupage'u w osiemnastowiecznych opisach krajobrazu. A jednak owe ograniczenia nie usuwają możliwości transtemporalnego związku i porównania, pozwalając na przykład Karlowi Heinzowi Bohrerowi rozwijać problem licznych powinowactw między wierszami Baudelaire'a i grecką tragedią ponad otchłanią różnicy historycznej ${ }^{11}$. Teksty to przedmioty, które dużo podróżują; przemieszczając się w czasie, wpadają w nowe sieci semantyczne, nowe sposoby przypisywania znaczenia. To, co Dimock nazywa rezonansem, to zdolność tekstu do znaczenia w różnych czasach, do wywoływania nieoczekiwanego echa w nowych miejscach.

Oczywiście Dimock nie dokonuje wykładni wpływu instytucji na literacką długowieczność. To, że pewne teksty przetrwały, a inne nie, nie wynika tylko z tego, że niektóre wchodzą w rezonans z poszczególnymi czytelnikami, ale również ze struktur oceny i nadzoru dostępu, selekcji i pomijania. Te procesy przesiewania, odbywające się codziennie w dyskusjach dotyczących tego, co opublikować, w czym ulokować środki na marketing albo jak poprawić sylabusy studentów, jednym dziełom umożliwiają istnienie $\mathrm{w}$ szerokim obiegu, a inne pomijają. $\mathrm{Z}$ tego

\footnotetext{
${ }^{10} \mathrm{~J}$. Fleissner, Is Feminism a Historicism?, „Tulsa Studies in Women's Literature” 2002, 21, nr 1, s. 45-66.

${ }^{11}$ K.H. Bohrer, The Tragic: A Question of Art, not Philosophy of History, „New Literary History” 2010, 41, nr 1, s. 35-51.
} 
punktu widzenia transtemporalna mobilność jest przynajmniej częściowo powiązana z instytucjonalną inercją. Cytaty generują kolejne cytaty, doktoranci uczą o tekstach, o których sami byli uczeni, kanony - czy to literackie, czy teoretyczne - reprodukują się wraz z biegiem czasu. Nawet jeśli nowe teksty przenikają do sali wykładowej, a sposoby czytania stopniowo się zmieniają, trudno wyobrazić sobie, jak mogłaby przebiegać edukacja bez elementarnego poziomu ciągłości, repetycji i przekazywania wcześniejszej wiedzy. Ale w ten sposób wzmacniam tylko to, co uważam za fundamentalne spostrzeżenia Latoura: że nie możemy, czystym aktem woli, odciąć się od wpływu przeszłości i że oddziaływanie dzieł sztuki - do tego argumentu niedługo się odwołam - jest uzależnione od ich społecznego osadzenia, a nie się mu sprzeciwia.

Co więcej, argumenty dotyczące tego, co kwalifikuje się jako „prawdziwy” kontekst, wychodzą daleko poza granice teoretycznych dyskusji w sferę monotonnych realiów naszego nauczania. Zwłaszcza na wydziałach anglistyki przypisanie do epoki pozostaje definiującym wyznacznikiem zawodowych kompetencji i jest ogłaszane w książkach opatrzonych przypisami, na konferencjach, w których wzięło się udział, na przeprowadzonych zajęciach i w zamieszczanych ofertach pracy. Wszystko sprzysięga się w celu umocnienia idei, że oryginalne historyczne znaczenie tekstu jest jego znaczeniem istotnym i zdewaluowania pozycji badaczy, którzy przechadzają się po kilku epokach historycznych, zamiast osiedlić się w jednej. „Może epoka, twierdzi Bruce Robbins - [...] powinna być postrzegana jako rodzaj pseudoantropocentrycznej normy, która przez długi czas była przyjmowana z lenistwa. To jeden z poziomów przybliżenia, nie mniej zasadny niż jakikolwiek inny, ale i nie mniej arbitralny"12. Robbins proponuje "gatunek" jako równie istotną kategorię, wokół której można organizować nauczanie literatury; kategorię, która jest o wiele bardziej gościnna wobec teoretyzacji transtemporalnych związków, powtórzeń i translacji. Mówiąc w skrócie, nie ma żadnego istotnego intelektualnego lub praktycznego powodu, dla którego oryginalny kontekst miałby pozostać rozstrzygającym autorytetem i sądem ostatniej instancji.

\section{Dzieła sztuki jako poza-ludzcy aktorzy}

Wiele z moich dotychczasowych propozycji zdaje się dość zgodnych z badaniami kulturowymi uprawianymi w duchu szkoły z Birmingham i jej modelem teorii artykulacji. W obu przypadkach daje się zauważyć nieufność wobec skrótów teoretycznych, niezadowolenie z modelu wyjaśniania-jako-redukcji i mocno wyostrzony sceptycyzm co do istnienia jakiegokolwiek koniecznego związku pomiędzy estetyką a polityką, pomiędzy strukturami formalnymi a społecznymi. Co więcej, badania kulturowe w sercu swego modelu kultury sytuują akt recepcji. $\mathrm{Z}$ zasady, choć nie zawsze w praktyce, zachęca to do politemporalnego spojrzenia na znaczenie tekstualne jako na coś aktywnie przetwarzanego z biegiem czasu przez nowe publiczności, jednocześnie wytłumiającego siłę jednostkowej chwili wytwarzania, by uwzględnić wiele momentów recepcji. W tym świetle inscenizacja Makbeta we wczesnosiedemnastowiecznym Londynie nie może poszczycić się żadnym specjalnym pierwszeństwem czy też przywilejem w stosunku do wielokrotnego dalszego życia sztuki na scenach Nowego Jorku i New Delhi, Sydney i Singapuru. Czyż owa otwartość na multitemporalność tekstów nie rozwiązuje - za jednym zamachem - trudności, na które wskazałam? Czy nie powinniśmy aby ochoczo uchwycić się tego na nowo spluralizowanego i pojemnego kontekstualizmu, miast wciąż smęcić, mędzić i narzekać?

${ }^{12}$ B. Robbins, Afterword, „PMLA” 2007, 122, nr 5, s. 1650. 
Sugeruję, że trudność z kontekstem tkwi nie tylko w powiązanym z nim tradycyjnym uprzedzeniu wobec pochodzenia historycznego, lecz również w jego milczących założeniach dotyczących sprawczości i nadzoru, jakie sterują aktami kontekstualizacji zarówno w badaniach kulturowych, jak i poza nimi. Kontekst jest częstokroć używany na dyscyplinującą modłę po to, aby pozbawić dzieło sztuki sprawczości, opróżnić je ze znaczenia oraz wpływu, aby uczynić z niego rzecz mizerną, wątłą, zubożoną. Jednym słowem, rozdmuchujemy kontekst, aby spuścić powietrze $z$ tekstu; podczas gdy świeżo wyolbrzymione warunki społeczne dzielą i rządzą, dzieło sztuki zaczyna migotać i tracić blask. Dlaczego wytwórcom i odbiorcom kultury zapewnia się władze tak wyjątkowe, a jednostkowym tekstom tak nikłe lub żadne? Czy owe teorie rzucają jakieś światło na to, dlaczego ludzie gotowi są jechać pięćset mil, aby posłuchać zespołu grającego konkretną piosenkę albo przez całe lata głowić się na doktoracie nad jedną powieścią? Pojęcia „kapitału kulturowego”, „hegemonicznego przemysłu medialnego”, czy „wspólnot interpretacyjnych” pomocne są jedynie w wyjaśnieniu, dlaczego to właśnie ten konkretny kawałek wciąż rozbrzmiewa nam w głowach albo dlaczego to Virginia Woolf staje się przedmiotem obsesji. Wyjaśniamy zagadkę naszego przywiązania, odwołując się do ukrytych ustaleń i utajonych interesów społecznych, podczas gdy skąpimy uwagi sposobom, w jakie teksty mogą zabiegać o nasze afekty, igrać z emocjami i żywić nasze fascynacje.

Oczywiście syreni śpiew Pani Dalloway albo Brown Eyed Girl nie rozlega się próżnym echem: żadne wyjaśnienie ich powabu nie umknie licealnej koterii, która wreszcie przekonała nas o geniuszu Van Morrisona; ambitnym rodzicom, których entuzjastyczne pochwały naszych wypracowań z drugiej klasy popchnęły nas ku doktoratowi; słowniczkom zamieszczanym w „Critical Inquiry” i „Rolling Stone”, które dały nam język do wysłowienia i uzasadnienia naszych obsesji. Ale co dokładnie zyskujemy poprzez zmniejszenie liczby czynników i zależności w grze, wzmocnienie i tak już daleko sięgającej władzy „kontekstu” kosztem „tekstu” w imię jakieś ostatecznej redukcji? Dlaczego musimy bagatelizować rolę, jaką dzieła sztuki odgrywają we własnym przetrwaniu, przymykać oczy na różnorodność dróg, którymi prześlizgują się do naszych serc i głów, na ich zmyślność w wytwarzaniu załączników?

Być może Latourowska idea poza-ludzkich aktorów jest w stanie przetrzeć szlak. Przede wszystkim, czym są aktorzy poza-ludzcy? Progi spowalniające, mikroorganizmy, kubki, statki, pawiany, gazety, narratorzy niewiarygodni, mydło, jedwabne sukienki, truskawki, plany piętra, teleskopy, spisy, obrazy, koty, otwieracze do puszek. Określenie owych radykalnie nieporównywalnych zjawisk mianem aktorów w żaden sposób nie oznacza przypisywania przedmiotom nieożywionym intencji, pragnień czy celów ani też ignorowania uderzających różnic pomiędzy rzeczami, zwierzętami, tekstami i ludźmi. W owym schemacie aktorem jest wszystko, co, wprowadzając różnicę, zmienia aktualną sytuację ${ }^{13}$. Trzymajmy się z daleka od technologicznego i tekstualnego determinizmu - poza-ludzcy aktorzy nie determinują rzeczywistości, ani też samodzielnie nie sprawiają, że coś się wydarza. A jednak, jak zauważa Latour, istnieje „wiele metafizycznych odcieni pomiędzy pełną przyczynowością a czystym nieistnieniem", pomiędzy statusem jedynego źródła działania a całkowitą bezwładnością i brakiem wpływu $^{14}$. „Aktor” w teorii aktora-sieci nie jest autosankcjonującym się podmiotem, nieza-

\footnotetext{
${ }^{13}$ B. Latour, Splatając na nowo..., s. 101.

${ }^{14}$ Tamże.
} 
leżnym agensem, który wywołuje działania i reżyseruje zdarzenia. Jest raczej tak, że aktorzy stają się aktorami jedynie poprzez ich relacje z innymi zjawiskami, jako mediatorzy i tłumacze połączeni w rozległe konstelacje przyczyny i skutku.

A zatem poza-ludzcy aktorzy pomagają zmienić sytuację; są uczestnikami łańcucha wydarzeń; pomagają kształtować wyniki i wpływają na działania. Uznanie wkładu takich aktorów oznacza omijanie - tak dalece, jak to tylko możliwe - dychotomii podmiotu i przedmiotu, natury i kultury, słowa i świata po to, aby osadzić ludzi, zwierzęta, teksty i rzeczy na tej samej płaszczyźnie ontologicznej i uznać ich współzależność. Progi spowalniające nie powstrzymają nas przed dodaniem gazu na podmiejskiej ulicy, ale ich obecność sprawia, że takie zachowanie staje się o wiele mniej prawdopodobne. Literackie narzędzie narratora niewiarygodnego zawsze może zostać przeoczone albo niezrozumiane, jednakże niezliczeni czytelnicy uczyli się na nim lektury pod włos i między wierszami. Istotność progów spowalniających i technik opowiadania bierze się z ich dystynktywnych cech, ich niewymiennych jakości - wszystkie one idą na marne, jeśli rozpuści się je w pojemniejszej teorii społecznej, jeśli będą postrzegane jedynie jako nosiciele z góry ustalonych funkcji. Jeśli jedna przyczyna służy do wyjaśnienia tysiąca różnych skutków, nie dowiadujemy się niczego na temat ich odmienności. Potraktowanie relacji pomiędzy jedwabiem i nylonem wyłącznie jako alegorii różnicy w smaku klasy wyższej i niższej - komentuje Latour, dając ukradkiem kuksańca Bourdieu - oznacza zredukowanie tych zjawisk do roli ilustracji już ustalonego schematu, pominięcie niesprecyzowanych, a zarazem fundamentalnych niuansów w kolorze, fakturze, połyskliwości i wrażeniu, które generują załączniki do tej lub innej tkaniny ${ }^{15}$. Inaczej mówiąc, jedwab i nylon nie są biernymi zapośredniczeniami, ale czynnymi mediatorami; nie stanowią jedynie kanału przekazywania ustalonych z góry znaczeń, ale w konkretny sposób owe znaczenia konfigurują i refigurują.

Co oznaczałoby dla badań literackich i kulturowych uznanie wierszy, obrazów, fikcyjnych bohaterów oraz narzędzi narracyjnych za aktorów ${ }^{16}$ ? Jak mogłoby się zmienić nasze myślenie? Oczywiście Babą Jagą jest tu estetyczny idealizm, lęk, że uznanie sprawczości tekstów popchnie nas ku otchłani uwsteczniającej religii sztuki i sprawi, że rozkwitną tysiące Bloomów ${ }^{17}$. Czy gdy zaczniemy rozmawiać o tym, że sztuka ma moc, by zmieniać nasze myślenie i uczucia, będziemy w stanie zostawić język transcendencji i ponadczasowy kanon daleko w tyle? „Każda rzeźba, obraz, danie haute cuisine, techno rave oraz powieśc”, zauważa Latour, „zostały «wyjaśnione od zera» przez czynniki społeczne «ukryte za» nimi. [...] Także i tutaj, jak zawsze w takich przypadkach, niektórzy ludzie rozwścieczeni lekceważeniem «wyjaśnień społecznych» występują naprzód, broniąc «wewnętrznej świętości» dzieł sztuki przed zalewem barbarzyństwa”18. Jak zaczynamy dostrzegać, z punktu widzenia teorii aktora-sieci żadna $\mathrm{z}$ tych perspektyw nie współgra. Chwały „tekstu” nie należy bronić, ratując go ze zniewalających szczęk „kontekstu”. Nie ma żadnej gry o sumie zerowej, w której jedna ze stron musi zostać ostatecznie zmiażdżona po to, aby

\footnotetext{
${ }^{15}$ Tamże, s. 57-58.

${ }^{16}$ Oddzielny - choć z intrygującymi podobieństwami - model sprawczości dzieł sztuki jest rozwijany przez Alfreda Gella w Art and Agency: And Anthropological Theory (Oxford 1998). Zob. także: adekwatne omówienie czerpiące zarówno z Gella, jak i Latoura w: Eduardo de la Fuente, The Artwork Made Me Do It: Introduction to the New Sociology of Art, „Thesis Eleven” 2010, 103, nr 1, s. 3-9.

${ }^{17}$ Aluzja do Harolda Blooma, którego nazwisko literalnie oznacza „kwiat” [przyp. tłum.].

${ }^{18}$ B. Latour, Splatając na nowo..., s. 344.
} 
druga mogła wznieść się w glorii. Nie jesteśmy już we władzy wizji - sentymentalnej i burzącej krew, lecz beznadziejnie chybiającej celu - walki między Dawidem i Goliatem, w której wszystkie chwyty są dozwolone, i w której wiersze i obrazy dzielnie dają odpór porządkowi społecznemu, albo (jeśli skłaniamy się ku melancholii) zostają wchłonięte przez otaczające je nikczemne siły.

Nasz punkt widzenia jest więc zgoła odmienny: autonomia dzieła sztuki - o ile jako autonomię rozumiemy jego wyrazistość i wyjątkowość - nie przekreśla łączliwości, lecz sama jest powodem tworzenia i podtrzymywania powiązań. Zacznijmy od tego, że nigdy nie było czegoś takiego jak wyizolowany samowystarczalny przedmiot estetyczny, jako że każdy taki przedmiot już dawno temu zostałby zassany przez czarną dziurę zapomnienia, a nie zwrócił naszą uwagę. Dzieła sztuki mogą przetrwać i prosperować jedynie dzięki zawiązywaniu przyjaźni, tworzeniu sojuszy, przyciąganiu uczniów, stymulowaniu załączników, uczepianiu się gościnnych żywicieli. Jeśli nie mają szybko zniknąć z pola widzenia, muszą przekonać ludzi do tego, aby wieszali je na ścianach, oglądali w kinach, kupowali na Amazonie, rozkładali na czynniki pierwsze w recenzjach, omawiali z przyjaciółmi. Owe sieci przymierzy, związków i translacji są równie fundamentalne dla życia sztuki eksperymentalnej, co i bestselerowej prozy, nawet jeśli same sieci różnią się co do rodzaju, a to, co uznaje się w nich za sukces, wygląda radykalnie odmiennie.

Liczba i rozpiętość owych sieci okazuje się o wiele bardziej istotna dla przetrwania tekstu niż kwestie porozumienia ideologicznego. Jeśli ktoś jest bezkompromisowym awangardzistą, który tworzy instalacje z brudnych pieluch i figurek Marii Dziewicy, jego sojusznikiem jest nie tylko pełna uznania recenzja w „ArtForum”, ale i konserwatywny ekspert, który przywołuje jego przypadek, aby pastwić się nad kondycją sztuki współczesnej, podbijając jej widoczność i wspominalność oraz wywołując lawinę komentarzy, czas antenowy w radiu publicznym i, parę lat później, wydanie krytyczne esejów. Z powodu romantycznych obrazów samotnej subwersji łatwo zapominamy, że rozłam znika bez śladu, o ile nie jest odnotowany i uznany, to znaczy, o ile nie stanie się przedmiotem nowych załączników, powiązań i translacji pomiędzy aktorami. Aby przetrwać, dzieła muszą być towarzyskie, niezależnie od ich stosunku do „towarzystwa". Albo zwięźlej: bez relacji nie ma negacji.

Nieodzownym elementem takiej towarzyskości - bez względu na to, jakie inne czynniki wchodzą w grę - jest sprawność dzieła w przyciąganiu czytelników lub widzów, w zabieganiu o załączniki i zachowywaniu ich. Gdy dołączamy do wijącej się w nieskończoność kolejki w kinie, gdy długo w noc pochłaniamy strona za stroną Jamesa Joyce’a albo Jamesa Pattersona, dzieje się tak, ponieważ konkretny tekst - ten a nie inny spośród niezliczonych możliwości - jakoś się dla nas liczy. Oczywiście to, jak się liczy, będzie się różniło, a modalności uznania, tak samo jak słowniki interpretacji, są mocno rozbieżne; „pytania do dyskusji” dołączone do typowej powieści dla klubu książkowego mogą wywołać ubaw po pachy na korytarzach wydziału anglistyki. Ale żaden fan, żaden entuzjasta, żaden wielbiciel - niezależnie od wykształcenia i pochodzenia klasowego - nie jest obojętny na wyjątkowość tekstu, który podziwia. I to właśnie w tym miejscu słowniki krytyczne wraz z ich naciskiem na modelowość, na abstrakcyjność i na logikę powieści realistycznej, albo poezji kobiecej, albo filmów hollywoodzkich, wykładają się przy próbie wyjaśniania praktyk dyskryminacyjnych wewnątrz takich grup gatunkowych, naszych wyraźnych preferencji dla pewnych tekstów kosztem innych i zaangażowania oraz namiętności, z jakimi częstokroć takich dyskryminacji się dokonuje. 
„Gdy tylko posłucha się, co ludzie mówią”, zauważa Latour, „okaże się, iż sami szczegółowo wyjaśniają, dlaczego zostali głęboko poruszeni, przywiq̨zani czy też ulegli wpływowi dzieł sztuki, które «spowodowały», iż poczuli pewne emocje"19. Dzieło Latoura jest między innymi nieustanną polemiką z nowoczesnym pragnieniem czystości: by oddzielać racjonalność od emocji, by zabezpieczać krytykę przed wiarą, by odróżniać fakty od fetyszy. W tym świetle doświadczenie dzieła sztuki - niczym Latoura przykłady języka religijnego albo mowy miłości - jest nie tylko kwestią przekazania informacji, ale również doświadczenia transformacji ${ }^{20}$. Istotność tekstu nie zostaje wyczerpana w tym, co on sam ujawnia lub skrywa na temat otaczających go warunków społecznych. Jest to raczej również kwestia tego, co umożliwia on w czytelniku lub widzu - jakiego rodzaju emocje wywołuje, jakie zmiany w postrzeganiu uruchamia, jakie więzi afektywne powołuje do istnienia. Na czym miałoby polegać oddanie sprawiedliwości tym reakcjom i nietraktowanie ich jako naiwnych, elementarnych albo ułomnych? Na byciu mniej zawstydzonym tym, że coś wstrząsa lub porusza, pochłania lub oczarowuje? Wykuciu języka bliskości [attachment] równie intelektualnie solidnego i wyszukanego, co nasza retoryka dystansu [detachment]?

Jedną z możliwych konsekwencji ANT w sali wykładowej jest zatem ujęcie mniej krytyczne wobec pospolitego doświadczenia czytania - włączenie go z marginesów profesjonalnej krytyki, na których do tej pory uparcie się utrzymywało. Nie chodzi już o spoglądanie przez owe doświadczenia na ukryte prawa, które nimi rządzą, ale o przyglądanie się im wprost, by zbadać tajemnice tego, co widać wyraźnie. Rzecz jasna, uczucia mają historie, a jednostkowe odczucia wzniosłości czy zatracenia włączają się w szerszą perspektywę i ramy kulturowe, ale podkreślanie faktu, że emocje są konstruktem społecznym, częstokroć wiąże się z oznajmianiem dystansu samego krytyka i jego odporności na złudzenia innych. Czy możemy sobie wyobrazić, że godzimy się z konsekwencjami naszego przywiązania [attachments] do określonych przedmiotów? Czy moglibyśmy odzwyczaić się od starego odruchu ignorowania albo opróżniania owych załączników [attachments], który miały służyć odkryciu, raz jeszcze, podskórnych struktur, które je determinują?

Ów odruch ma tendencję do umacniania się nawet w najbardziej wyszukanych interpretacjach recepcji. Na przykład, dobrze znane pojęcie „formacji czytelniczej” u Tony’ego Bennetta dąży do tego, aby pośredniczyć pomiędzy internalistycznymi i eksternalistycznymi teoriami znaczenia, pomiędzy tekstocentrycznymi teoriami rezonansu czytelniczego i redukcyjnością konwencjonalnego wyjaśnienia socjologicznego. W zamian za to Bennett kieruje uwagę na „dyskursywne i intertekstualne determinanty, które organizują i ożywiają praktykę czytania"21. Innymi słowy, to jak reagujemy na dzieła sztuki, nie jest określane ani przez wewnętrzne struktury tekstu, ani przez samą społeczną demografię rasy, płci kulturowej albo klasy, ale przez ramy kulturowe i słowniki interpretacyjne, które nieświadomie przyswoiliśmy. Idea formacji czytelniczej rzeczywiście uchwytuje zasadnicze aspekty mediacji, uwypuklone przez

\footnotetext{
${ }^{19}$ Tamże.

${ }^{20}$ Moje poglądy w tej kwestii oparłam na artykule Thoma Dancera, Between Knowledge and Belief: J. M. Coetzee, Gilles Deleuze and the Present of Reading oraz książki Cristiny Visher Bruns, Why Literature? The Value of Literary Reading and What it Means for Teaching (New York 2011).

${ }^{21} \mathrm{~T}$. Bennett, Texts in History: The Determination of Readings and their Texts, „The Journal of the Mid-West Modern Language Association" 1985, 18, nr 1, s. 7.
} 
twierdzenie Bennetta, że znaczenie jest z natury relacyjne i że teksty istnieją jedynie w użyciu. Odrzucając jakiekolwiek pojęcie „tekstu jako takiego” jako ostatnie tchnienie kantowskiego idealizmu, Bennett niezłomnie obstaje przy tym, że teksty nie istnieją „uprzednio albo niezależnie od zmiennych «formacji czytelniczych», wewnątrz których zostały ukonstytuowane jako przedmioty-do-czytania"22.

A jednak, użycie strony biernej i wybór rzeczownika („przedmioty-do-czytania”) wiele mówi, akcentując wizję tekstów raczej jako czegoś, na co się oddziałuje, niż czegoś co działa. Filmy i powieści rozpuszczają się w założeniach kulturowych i modelach interpretacyjnych ich publiczności; tak, jak opisał to Bennett, zdają się nie mieć niezależnej egzystencji, wyróżniających cech, siły, własnej obecności. Marnujemy okazję, by uświadomić sobie częstokroć nieprzewidziany wpływu tekstów: piosenka w radiu, która niespodziewanie doprowadza nas do łez; ociekający krwią horror, który nawiedza nasze sny; powieść, która wreszcie przekonała nas do tego, aby zostać buddystą albo wziąć rozwód. Niczym we wspólnotach interpretacyjnych Stanleya Fisha tekst jest zredukowany do pustego ekranu, na który grupy czytelników projektują swoje wcześniejsze idee i przekonania. W rezultacie znajdujemy się w trudnym położeniu, gdy próbujemy wyjaśnić, dlaczego jakiś tekst powinien się liczyć bardziej od innego, dlaczego tak silnie odnotowujemy różnice pomiędzy poszczególnymi tekstami albo jak to możliwe, że jesteśmy pobudzeni, zaniepokojeni, zaskoczeni albo przywiedzeni do działania przez takie teksty w nieoczekiwane i niełatwo wytłumaczalne sposoby. Jak przyznaje sam Bennett, kontekst przewyższa i przekracza tekst.

A jednak, skoro konteksty Bennetta same są tekstualne - mianowicie: słowniki krytyczne i ramy interpretacyjne $-\mathrm{z}$ trudem przychodzi zrozumienie, dlaczego tak miałoby być, dlaczego owe ramy powinny mieć wyłączną władzę określania znaczenia, podczas gdy filmom i powieściom nie przyznaje się żadnej. Dlaczego zamrażać pojedynczą relację pomiędzy figurą a tłem, przedmiotem i ramą, dlaczego nie uznać, że dzieła sztuki mogą funkcjonować zarówno jako środki poznania, jak i przedmioty do poznania, dlaczego nie zrobić miejsca dla mnogości mediatorów? Choć nie podlega dyskusji, że uczymy się lektury tekstów literackich poprzez internalizację poszczególnych słowników interpretacyjnych, na tej samej zasadzie uczymy się czytać nasze życia i nadawać im sens, odnosząc je do fikcyjnych i wyobrażonych światów. Co liczy się jako tekst, a co służy za ramę, jest bardziej zmienne i płynne niż chciałby Bennett; dzieła sztuki mieszczą się raczej w obu kategoriach, a nie w jednej; nie są jedynie przedmiotami do interpretacji, ale również punktami odniesienia i przewodnikami po interpretacji, zarówno na bardziej, jak i na mniej przewidywalne sposoby.

W rzeczywistości praktyka krytyczna samego Bennetta jest bardziej elastyczna, niż niektóre jego wypowiedzi teoretyczne mogłyby sugerować. Usunięcie sprawczości z tekstów fikcjonalnych drastycznie przeszkadzałoby w zadaniu, jakie Bennett stawia przed sobą w książce pisanej wspólnie z Janet Woollacott: wyjaśnieniu, dlaczego powieści i filmy o Jamesie Bondzie osiągnęły światowy sukces, dlaczego stały się uczestnikami tak wielu sieci, przyciągając wciąż nowych pośredników, wytwarzając wciąż nowe załączniki, aż wreszcie cała planeta wydała się zasypana filmami z Bondem, książkami, reklamami, plakatami, koszulkami, za-

${ }^{22}$ T. Bennett, J. Woollacott, Bond and Beyond: The Political Career of a Popular Hero, London 1987, s. 64. 
bawkami i rekwizytami. Fenomen Bonda był bezdyskusyjnie kształtowany przez kaprysy recepcji; dowiadujemy się, że powieści Iana Fleminga były kojarzone w Stanach Zjednoczonych z tradycją pozbawionej sentymentów powieści kryminalnej, podczas gdy w Wielkiej Brytanii zyskiwały na popularności imperialnego thrillera szpiegowskiego. Ale takie komentarze nie wyjaśniają, dlaczego ta właśnie seria powieści zmierzała ku światowej rozpoznawalności i istotności, podczas gdy niezliczone inne powieści szpiegowskie marniały, podpierając ściany na półkach z przecenami i piętrząc się w koszach z nadwyżkami nakładu. Co takiego miały w sobie właśnie powieści o Jamesie Bondzie, że przyciągnęły tak wielu sojuszników, fanów, entuzjastów, tłumaczy, marzycieli, reklamodawców, przedsiębiorców i parodystów? Z pewnością ich obecność wprowadziła zmianę; przyciągnęły współaktorów; sprawiły, że coś się wreszcie stało.

Co więcej, Latourowski model aktora poza-ludzkiego nie zakłada żadnej koniecznej jednostki skali, rozmiaru albo złożoności. Zawiera nie tylko poszczególne powieści czy filmy, ale także postaci, mechanizmy fabularne, kinematografię, style literackie i inne narzędzia formalne, które wykraczają poza granice swoich tekstów macierzystych po to, by przyciągać sojuszników, generować załączniki, uruchamiać translacje oraz inspirować kopie, spin-offy i klony. Innymi słowy, jesteśmy daleko od estetyzmu, w którym dzieła sztuki są cnotliwie odizolowane od zgiełku świata, a ich poszczególne części odnoszą się tylko do siebie nawzajem. Powab tekstów Fleminga, według wiarygodnej hipotezy Bennetta i Woolacott, miał wiele wspólnego z kreacją charyzmatycznego bohatera, który z łatwością wędrował pomiędzy różnorodnymi mediami, czasami i przestrzeniami oraz był zdolny do przystosowania się do interesów i emocji różnorakich publiczności. Postaci z bardziej elitarnych środowisk mogą być równie pełne życia, uruchamiając nowe połączenia wraz z podróżami w przestrzeni i czasie: pomyślmy o światowych obchodach Bloomsday albo życiu pośmiertnym Emmy Bovary jako o wciąż ważnym probierzu dla określonego rodzaju czytelnika.

Oczywiście większość fikcyjnych bohaterów rodzi się tylko po to, aby przeminąć w niemal niestosownym pośpiechu. Franco Moretti w artykule Rzeźnia literatury (The Slaughterhouse of Literature) przywołuje opuszczone obszary literackiego cmentarzyska: nawet jeśli niektóre dzieła okazują się niezwykle żywotne, przeskakując czas i przestrzeń, zasadniczą większość szybko tracimy z pola widzenia - dziewięćdziesiąt dziewięć i pół procent, według Morettiego, nawet we względnie powściągliwym środowisku wydawniczym wiktoriańskiej Anglii. Dlaczego niektóre teksty żyją dalej, a tak wiele przepada? Według Morettiego odpowiedź tkwi w sile formy. Śledząc przemiany powieści detektywistycznej, przekonuje, że wynalazek pewnego narzędzia formalnego - mianowicie: techniki wskazówki - pomaga wyjaśnić długowieczność Sherlocka Holmesa i szybkie starzenie się większości jego fikcyjnych rówieśników ${ }^{23}$. Wskazówka, posługując się terminologią Latoura, funkcjonowała jako aktor, a powody przetrwania Holmesa nie były ani arbitralne, ani czysto ideologiczne (Arthur Conan Doyle był apologetą patriarchalnej racjonalności, ale było nimi również wielu jego rodaków, których dzieła przepadły bez śladu). Niezależnie od tego, czy nasza próbka składa się ze sztuk renesansowych, modernistycznych wierszy czy hollywoodzkich hitów, pewne przykłady okażą się bardziej niż inne mobilne, przenośne i dające się przystosować do interesów różnych publiczności. 
A jednak również i struktura społeczna, siła nabywcza oraz przekonania publiczności są dla równania bardziej kluczowe niż Moretti jest gotów to uznać. Mimo wszystko, formalne właściwości tekstu nie są w stanie samodzielnie zdecydować o jego ponadczasowym zasięgu i określić go, jest on bowiem zależny także od kaprysów i kontyngentności jego relacji z wieloma innymi aktorami - ludźmi, innymi tekstami, instytucjami. Teksty literackie stają się modne i wychodzą z mody; to, co kiedyś było nieodzowne, dziś zdaje się przestarzałe i już niemodne, a dzieła przeoczone w chwili pierwodruku mogą zyskać intensywne, wręcz frenetyczne, dalsze życie. Powody owych przesunięć są tyleż tematyczne oraz polityczne, co i formalne; to, że akcje Hemingwaya spadają, a Kate Chopin systematycznie zdobywa rozpoznawalność i prestiż, z trudem daje się wytłumaczyć jedynie za pomocą samych mechanizmów literackich. Teksty nie działają samodzielnie, ale zawsze wraz z niezliczonymi innymi, częstokroć nieprzewidywalnymi współaktorami.

\section{Wnioski}

Jak sugeruję, przetrawienie konsekwencji tego pomysłu wymaga odejścia od bardziej oswojonych sposobów przydzielania - przy użyciu rozróżnienia tekst/kontekst - sprawczości i władzy. Oczywiście jedną z możliwości byłoby nie porzucanie tego rozróżnienia, lecz przedefiniowanie go, sprawienie, by pojęcie kontekstu stało się bardziej apetyczne. Obstawiam jednak, że bezlitosna presja wcześniejszych użyć kontekstu, prawdopodobnie nakłoni nas do powrotu do znanych sposobów myślenia: pojemnik versus zawartość, przymus versus opór. $\mathrm{Na}$ tym polegała widoczna na poprzednich stronach podejrzliwość wobec przekonania, że studiowane teksty są trwale wplątane w oszałamianie, przymuszanie i oszukiwanie czytelników. W takich scenariuszach teksty jedną ręką hojnie obdarza się mocami supermana, tylko po to, by drugą natychmiast im je odebrać. Powieść zostaje oskarżona i uznana za winną produkcji potulnych podmiotów burżuazji, ale owo osiągnięcie, od którego opada szczęka - tak nadzwyczajne, jeśli tylko jest prawdziwe! - okazuje się jedynie marnym odbiciem systemów władzy, które zza kurtyny pociągają za sznurki, tajemnych sił kontekstualnych, które całkowicie determinują, same nie podlegając determinacji. W takich scenariuszach teksty wychodzą nie na czynnych mediatorów, ale raczej na bierne zapośredniczenia, służalczych giermków, najemników gotowych na każde skinienie i wezwanie ich tajemniczych, wszechmocnych i wszystko widzących panów ${ }^{24}$.

Jednakowoż niedostatki tego scenariusza nie powinny powieść nas $\mathrm{w}$ ramiona równie lubianego idiomu subwersji, oporu, negacji, transgresji i zerwania. Jak przekonuję, dzieła literackie nie są aktorami w owym szorstkim, indywidualistycznym sensie, nie są samotnymi buntownikami walczącymi na arenie z nieprzejednanymi siłami kontekstowego status quo. Jeśli wprowadzają różnicę, dokonują tego jedynie jako współzależni współaktorzy wplątani w różnobarwną sieć załączników i powiązań. Siłę i witalność czerpią ze swych sojuszy; „Emancypacja”, zauważa Latour, „nie oznacza [...] «wolny od więzi», ale «dobrze-połączony»” 25 . Pociąg teorii do retoryki marginalności i negatywności nie pozwala nam dostrzec, że towarzyskość tekstu - to znaczy jego osadzenie w licznych sieciach i jego poleganie na wielu mediatorach - nie jest wyczerpywaniem, umniejszaniem ani przejmowaniem jego sprawczości, ale jej koniecznym

\footnotetext{
${ }^{24}$ Powinnam zwrócić uwagę, że odrzucenie takiego scenariusza nie powstrzymuje nas przed sprzeciwianiem się temu, co tekst mówi, czy to na płaszczyźnie politycznej, czy jakiejkolwiek innej, a jedynie przed umacnianiem naszych roszczeń poprzez opieranie ich na określonej ontologii fikcji albo teologii władzy.

${ }^{25}$ B. Latour, Splatając na nowo..., s. 318.
} 
warunkiem. Dzieła, które studiujemy i których uczymy - włączając w to najbardziej antynomiczne teksty Becketta i Blanchota, Brechta i Butler - nigdy nie znalazłyby się w polu naszej uwagi, gdyby nie wkład niezliczonych współaktorów: wydawców, reklamodawców, krytyków, kapituł nagród, recenzji, rekomendacji przekazywanych drogą ustną, decyzji wydziałowych, sylabusów starych, sylabusów nowych, podręczników i antologii, zmieniających się smaków krytycznych i akademickich słowników, wreszcie załączników i pragnień nas samych i naszych studentów. Z pewnością niektórzy z tych mediatorów okażą się bardziej pomocni, atrakcyjni, hojni i będą darzyć swe przedmioty większym szacunkiem niż inni, jednak fakt mediacji nie jest godnym ubolewania popadnięciem we współudział albo zmowę, ale fundamentalnym warunkiem koniecznym, by być znanym. Dzieła literackie i krytyczne, które nie byłyby kupowane, czytane, recenzowane, nauczane, gniłyby w limbo - na zawsze niewidzialne i bezsilne.

Tymczasem nasze konwencjonalne modele kontekstu zgarniają owe wielokierunkowe wiązania do przypominających trumny pojemników zwanych epokami. Zamiast mrowia zmierzających ku sobie aktorów wyobrażamy sobie nieruchomy obiekt tekstualny, zamknięty w ramie kontekstualnej, która wszystko determinuje. Dzieło literackie zastygłe w czasie i przestrzeni zostaje pozbawione owej mobilności, dzięki której możemy w ogóle go doświadczyć. Nadziane na szpilkę naszych kategorii i współrzędnych historycznych, istnieje jedynie jako przedmiot-do-wyjaśniania, a nie współaktor i współtwórca relacji, stosunków i załączników. Oczywiście wszystko, co zostało do tej pory powiedziane, podkreśla niemożność prostego obalenia, przekroczenia czy unieważnienia kategorii należących do naszej własnej historii intelektualnej. Pojęcie kontekstu samo jest aktorem, który cieszył się nadzwyczaj długą i udaną karierą. Ale jak mogłoby się zmienić nasze myślenie, gdybyśmy, a z pewnością możemy tak zrobić, tymczasowo zawiesili kontekst, gdybyśmy nakierowali się na zadawanie innych pytań i głowienie się nad problemami innego rodzaju?

przeł. Krzysztof Hoffmann i Weronika Szwebs 


\title{
SEOWA KLUCZOWE:
}

hermeneutyka podejrzeń

\section{BRUNO LATOUR}

\begin{abstract}
AbSTRAKT:
Niniejszy artykuł czerpie z prac Bruno Latoura, aby zakwestionować konwencjonalne metody „historycyzacji” i „kontekstualizacji” dzieł sztuki. Zwyczajowo za kontekst uznaje się oryginalny kontekst historyczny, a akt historycyzacji tekstu polega na połączeniu go z innymi tekstami i zdarzeniami wewnątrz tego samego odcinka czasu. W artykule przekonuję, że takie podejście historystyczne nie jest w stanie wyjaśnić transtemporalnych ruchów tekstów, ich zdolności do rezonowania w różnych okresach i sposobów, na jakie do nas dzisiaj przemawiają. Co więcej, tradycyjne modele kontekstu i jego korelatów (społeczeństwa, władzy, ideologii, itp.) zwykle pomniejszają lub jawnie negują sprawczość dzieł sztuki. Co by się stało, gdybyśmy pomyśleli o owych dziełach jako pozaludzkich aktorach, którzy zmieniają aktualną sytuację, wprowadzając różnicę? Takie podejście wymaga od nas rozpoznania specyfiki dzieł sztuki oraz ich towarzyskości i światowości. Dzieła sztuki nie są heroicznymi aktorami zaangażowanymi w nieskończony sprzeciw, subwersję i opór; są raczej współzależnymi współaktorami zanurzonymi w sieć różnorodnych załączników i powiązań, które pozwalają im przetrwać.
\end{abstract}




\section{kontekst}

\section{NOTA O AUTORZE:}

Rita Felski zajmuje stanowisko William R. Kenan Jr. Professor of English na University of Virginia. Jest redaktorką New Literary History. W swych badaniach intensywnie zajmuje się teorią literatury i estetyką, modernizmem i postmodernizmem, teorią feministyczną i studiami kulturowymi. Jej najnowsze książki to Uses of Literature (2008; wyd. polskie Literatura w użyciu, 2016), The Limits of Critique (2015) oraz Critique and Postcritique (2017). Aktualnie pracuje nad książką o załącznikach (attachments) do dzieł sztuki. Zajmuje również stanowisko Niels Bohr Professor na University of Southern Denmark, gdzie kieruje projektem badawczym o „Literaturze w użyciu”. 